\title{
Effects of Grape Seed Oil on Liver of Rats
}

Afnan M. Amer

Department of zoology, Girls College for Arts, Science and Education, Ain Shams University

\begin{abstract}
OBJECTIVES: To study the effect of oral administration of grape seed oil (GSO) against carbontetrachloride (CCl4)-induced hepatotoxicity in rat Liver damage was induced in male Wistar rats (150-200 g) by administering CCl4 $(0.5 \mathrm{ml} / \mathrm{kg}$, i.p.) once per day for 7 days and the extent of damage was studied by assessing biochemical parameters such as alanine aminotransferase (ALT), aspartate aminotransferase (AST), and alkaline phosphatase (ALP) in serum and concentrations of glutathione (GSH), superoxide dismutase (SOD), and total protein (TP) in liver. The effect of coadministration of GSO $(3.7 \mathrm{~g} / \mathrm{kg}$, orally) on the above parameters was further investigated and compared with a vitamin $E(100 \mathrm{mg} / \mathrm{kg}$, orally) treated group.

RESULTS: Oral administration of GSO (3.7 g/ $/ \mathrm{gg}$, body weight orally) for 7 days resulted in a significant reduction in serum AST, ALT, and ALP levels and significant improvement in glutathione, $S O D$, and TP, when compared with CCl4 damaged rats. The antioxidant effect of GSO at $3.7 \mathrm{~g} / \mathrm{kg}$ for 7 days was found to be comparable with vitamin $E$ (100 $\mathrm{mg} / \mathrm{kg}$, orally) in CCl4-treated rats.

CONCLUSION: The GSO has protected the liver from CCl4 damage. Probable mechanism of action may be due to the protection against oxidative damage produced by CCl4.
\end{abstract}

Key Words: Grape seed oil and liver function

\section{INTRODUCTION}

Grape seed oil (GSO) is obtained from grape seeds after the wine pressing in Italy and France. The GSO contains $75 \%$ linoleic acid, $15 \%$ oleic acid, $6 \%$ palmitic acid, $3 \%$ stearic acid, and $1 \%$ linolenic acid. ${ }^{[1]}$

Studies revealed the beneficial HDL effect of GSO and research shows that subjects were instructed to use up to $45 \mathrm{ml}$ of GSO in their daily diet as a substitute for their usual oil and within 2 weeks there was $13-14 \%$ increase in HDL level. ${ }^{[2]}$ The GSO has a very high level of antioxidant vitamin E (60-120 mg/100 g), which makes the oil very stable. The antioxidant property is claimed to be the mechanism of hepatoprotective activity. ${ }^{[3]}$ The GSO exhibits a variety of interesting properties such as reducing platelet aggregation, prevents hypertension caused by sodium excess, normalizes lesions occurring from obesity and diabetes. ${ }^{[4]}$

Among the various mechanisms involved in the hepatotoxic effect of carbontetrachloride (CCl4), one is oxidative damage through free-radical generation ${ }^{[5]}$ and antioxidant property is claimed to be one of the mechanisms of hepatoprotective effect of indigenous drugs. ${ }^{[6]}$ The GSO has antioxidant properties. ${ }^{[2],[3]}$ Hence, the objective of the study was to evaluate 
the effect of GSO on CCl4-induced hepatotoxicity.

\section{MATERIALS \& METHODS}

\section{Drugs and chemicals}

The GSO is a kind gift from LoDuca

Bros Inc., Milwaukee, USA.

Carbontetrachloride (CCl4) was

obtained from Sigma.

Experimental animals

Male Wistar albino rats (150$200 \mathrm{~g}$ ) were used. The animals were acclimatized to laboratory conditions for 5 days prior to the experiments and had access to food and water ad libitum.

\section{Selection of dose of GSO}

The dose for the hepatoprotective studies was adjusted based on the observation during the toxicity studies. The GSO at a dose of $3.7 \mathrm{~g} / \mathrm{kg}$ ( $4 \mathrm{ml} / \mathrm{kg}$ ) was administered orally to study the hepatoprotective activity.

\section{Hepatoprotective studies}

Animals were divided into five groups, consisting of six animals each. Group I: served as control which recieved orally for 7 days. Group II received GSO $(3.7 \mathrm{~g} / \mathrm{kg}$, orally) for 7 days. Group III received CCl4 0.5 $\mathrm{ml} / \mathrm{kg}$, i.p. for 7 days. ${ }^{[9],[10],[11]}$ Group IV received CCl4 $0.5 \mathrm{ml} / \mathrm{kg}$, i.p. and GSO (3.7 g/kg, orally) simultaneously for 7 days. Group V received $\mathrm{CC} 14$ $0.5 \mathrm{ml} / \mathrm{kg}$, i.p. and vitamin E (100 $\mathrm{mg} / \mathrm{kg}$, orally) ${ }^{[12]}$ simultaneously for 7 days. After 7 days of treatment, the rats were kept overnight fasting and killed. At the end of the treatment, blood samples were collected by direct cardiac puncture under ether anaesthesia and the serum was used for the assay of marker enzymes mainly, aspartate aminotransferase
(AST), alanine aminotransferase (ALT), and alkaline phosphatase (ALP). ${ }^{[13],[14]}$ The enzyme levels were assayed using the standard kits from laboratories. The results were expressed as units/liter (U/l). Liver samples were dissected out and washed immediately with ice-cold saline to remove as much blood as possible. Liver homogenates $(5 \% \mathrm{w} / \mathrm{v})$ were prepared in cold $50 \mathrm{mM}$ potassium phosphate buffer $(\mathrm{pH} 7.4)$ using homogenizer. The unbroken cells and cell debris were removed by centrifugation at $1000 \mathrm{rpm}$ for $10 \mathrm{~min}$. The supernatant was used for the estimation of $\mathrm{GSH}^{[15]}$ superoxide dismutase (SOD), ${ }^{[16]}$ and total protein (TP $)^{[17]}$ levels.

\section{Statistical analysis}

Values were represented as mean + SE. Data were analyzed using oneway analysis of variance (ANOVA) and group means were compared using Duncan's multiple range test. $\mathrm{P}$ values $<0.05$ were considered significant. ${ }^{[18]}$

\section{RESULTS}

In acute toxicity study, no signs, and symptoms of toxicity and mortality were observed. There was a significant $(\mathrm{P}<0.05)$ increase in the serum hepatic enzyme levels after $\mathrm{CCl} 4$ treatment, which was prevented with GSO. The GSO when administered alone did not alter the enzyme levels when compared to the control values. There was a significant $(\mathrm{P}<0.05)$ rise in $\mathrm{GSH}$, SOD contents of liver after treatment with GSO. There was a significant decrease in TP level after $\mathrm{CCl} 4$ treatment, which was prevented with GSO [Table - 1] and [Table - 2]. 
Table 1: Effect of GSO on serum ALT, AST, and ALP in rats after 7 days treatment

\begin{tabular}{|l|l|l|l|}
\hline Groups & ALT (U/l) & AST (U/l) & ALP (U/I) \\
\hline Control & $51.3 \pm 4.3^{*}$ & $266.3 \pm 66.7^{*}$ & $1006.3 \pm 126.5^{*}$ \\
\hline GSO $(3.7 \mathrm{~g} / \mathrm{kg})$ & $59.9 \pm 5.7^{*}$ & $255.6 \pm 53.0^{*}$ & $1097.0 \pm 4.5^{*}$ \\
\hline $\mathrm{CCl} 4(0.5 \mathrm{ml} / \mathrm{kg}, \mathrm{I}, \mathrm{p})$, & $231.6 \pm 12.4^{* *}$ & $695.3 \pm 116.6^{* *}$ & $1479.4 \pm 311.6^{* *}$ \\
\hline $\mathrm{CCl} 4+\mathrm{GSO}(3.7 \mathrm{~g} / \mathrm{Kg})$ & $73.3 \pm 7.3^{* * *}$ & $292.8 \pm 93.0^{* * *}$ & $1124.3 \pm 21.6^{* * *}$ \\
\hline $\mathrm{CCl} 4+\mathrm{VE}(100 \mathrm{mg} / \mathrm{kg})$ & $74.3 \pm 7.3^{*},,^{* *}$ & $291.3 \pm 13.4^{*}, * * *$ & $1146.8 \pm 114.0^{*}, *^{* *}$ \\
\hline $\mathrm{F}$ & 58.3 & 117.9 & 245.9 \\
\hline d.f. & 4,25 & 4,25 & 4,25 \\
\hline $\mathrm{P}$ & $<0.05$ & $<0.05$ & $<0.05$ \\
\hline
\end{tabular}

Values are mean $\pm \mathrm{SE} ; \mathrm{n}=6$ in each group. Values with different superscripts $\left(*, * *\right.$ and $\left.{ }^{* * *}\right)$ differ significantly from each other at $\mathrm{p}<0.05$ ( Duncan 's multiple range test )

Table 2: Effect of GSO on liver GSH, SOD, and TP in rats after 7 days treatment

\begin{tabular}{|l|l|l|l|}
\hline \multicolumn{1}{|c|}{ Groups } & \multicolumn{1}{|c|}{$\begin{array}{c}\text { GSH } \\
\text { Mg/100g } \\
\text { Tissue }\end{array}$} & $\begin{array}{c}\text { SOD } \\
\text { Units/mg } \\
\text { Protein }\end{array}$ & \multicolumn{1}{|c|}{$\begin{array}{c}\text { Total } \\
\text { Mg/mi } \\
\text { Protein }\end{array}$} \\
\hline Control & $39.8 \pm 11.8^{*}$ & $7.70 \pm 0.25^{*}$ & $17.15 \pm 1.34^{*}$ \\
\hline GSO $(3.7 \mathrm{~g} / \mathrm{kg})$ & $37.0 \pm 2.2^{*}$ & $7.81 \pm 0.22^{*}$ & $16.42 \pm 3.5^{*}$ \\
\hline $\mathrm{CCl} 2(0.5 \mathrm{~m} / \mathrm{kg} \mathrm{i.p)}$ & $18.8 \pm 1.8^{* *}$ & $4.51 \pm 0.09^{* *}$ & $7.70 \pm 0.70^{* *}$ \\
\hline $\mathrm{CCl}+\mathrm{GSO}(3.7 \mathrm{G} / \mathrm{KG})$ & $35.6 \pm 4.5^{* * *}$ & $5.04 \pm 0.34 * * *$ & $15.30 \pm 0.16^{* * *}$ \\
\hline $\mathrm{CCl} 4+\mathrm{VE}(100 \mathrm{mg} / \mathrm{kg})$ & $37.3 \pm 4.1^{*}$ & $7.48 \pm 0.24^{*}$ & $17.16 \pm 5.60^{*}$ \\
\hline F & 22.4 & 4.67 & 3.47 \\
\hline d.f & 4.25 & 4.25 & 4.25 \\
\hline P & $<0.05$ & $<0.05$ & $<0.05$ \\
\hline
\end{tabular}

Values are mean \pm SE; $n=6$ in each group. Values with different superscripts $\left(*, * *\right.$ and $\left.{ }^{* * *}\right)$ differ significantly from each other at $\mathrm{p}<0.05$ (Duncan $\mathrm{s}$ multiple range test )

\section{DISCUSSION}

The $\mathrm{CCl} 4$ is one of the most commonly used hepatotoxins in the experimental study of liver diseases.[19] The lipid peroxidative degradation of biomembranes is one of the principal causes of hepatotoxicity of $\mathrm{CCl} 4{ }^{[20]}$ This is evidenced by an elevation in the serum maker enzymes, namely AST, ALT, and ALP. The GSO has significantly reduced these liver enzyme levels. Further, GSO has increased the level of TPs, which indicates hepatoprotective activity.

Stimulation of protein synthesis accelerates the regeneration process and the production of liver cells. In our study, elevation in the levels of lipid peroxidation in CCl4-treated animals was observed. Maheswory, ${ }^{\text {[21] }}$ found that the increase in MDA and hydroperoxide levels in liver with $\mathrm{CCl} 4$ suggests that enhanced lipid peroxidation leads to tissue damage and failure of 
antioxidant defence mechanisms. Treatment with GSO significantly prevented these changes. Hence, the mechanism of hepatoprotection of GSO may be due to its antioxidant effect. Since GSO has significantly increased the glutathione, and SOD contents of the liver, it may also be useful in hepatotoxicity induced by other agents. The antioxidant enzyme levels of the CCl4-treated group were decreased whereas that of GSOtreated group is almost similar to that of the control and vitamin-E-treated groups.

Pretreatment with GSO exhibited protection, which confirmed the results of biochemical studies. These results of our study indicate that simultaneous treatment with GSO protects the liver against $\mathrm{CCl} 4$ induced hepatotoxicity.

The GSO offers vast possibilities in the treatment of various liver disorders. This may be due to the high level of antioxidant vitamin $\mathrm{E}$, which was claimed to be the mechanism of hepatoprotection. Further studies on any other models and extensive clinical trials are needed to confirm these results.

\section{REFERENCES}

1. Natella F, Belleli F, Gentili V, Ursini F, Scaccini C. (2003): Grape seed proanthocyanidins prevent plasma post prandial oxidative stress in humans. J Agric Food Chem 26:7720-5.

2. Nash DT, Nash SD. (1993): Grape seed oil, a natural agent which raises serum HDL levels. J Am Coll Cardiol 21:318-20.
3. Bagchi D, Bagchi M, Stohs S, Ray SD, Sen CK, Preuss HG. (2002): Cellular protection with proanthocyanidins derived from grape seeds. Ann NY Acad Sci 957: 260-70.

4. Bagchi D, Ray SD, Bagchi M, Preuss HG, Stohs SJ. (2002): Mechanistic pathways of antioxidant cytoprotection by a novel IH 636 grape seed proanthocyanidin extract. Indian J Exp 6:717-26.

5. DeLeve LD, Kaplowitz $\mathbf{N}$. (1995): Mechanisms of drug induced liver diseases. Gastroenterol Clin N Am 24:787810.

6. Bhat AD, Bhat S. (1996): Indigenous drugs and liver diseases. Indian J Gastroen15:637.

7. Paget GE, Barnes JM.: In: Evaluation of drug activities. Pharmacometrics. Lawrence DR, Bachrach AL, editors. Vol. 1. New York: Academic Press; 1964.

8. OECD (2000): Acute oral Toxicity - Acute oral toxic class method. Guideline 423, adopted 23.03.1996. In: Eleventh Addendum to the OECD guidelines for the Testing of Chemicals. Organisation for Economic Co-Operation and Development, Paris, June 2000.

9. Rao PGM, Rao SG, Kumar V. (1993): Effect of Hepatogard against carbontetrachloride induced liver damage in rats. Fitoterapia 64:108-13.

10. Dwivedi Y, Rastogi R, Chander R, Sharma SK, Kapoor NK, Garg NK, et al. (1990): 
Hepatoprotective activity of Picroliv against carbontetrachloride induced liver damage in rats. Indian J Med Res 92:195-200.

11. Kataria M, Singh LN. (1997): Hepatoprotective activity of Liv 52 and Kumaryasava on carbontetrachloride induced hepatic damage in rats. Indian $\mathrm{J}$ Exp Biol 35:655-7.

12. Sheweita SA, Abd El-Gabar M, Bastawy M. (2001): Carbon tetrachloride induced changes in the activity of Phase II drug metabolizing enzymes. Toxicology 165:217-24.

13. Reitman S, Frankel S.(1957) A colorimetric method for the determination of SGOT and SGPT. Am J Clin Pathol 28:5663.

14. Kind PRN, Kings EJ. (1954): Estimation of plasma phosphatase by determination of hydrolysed phenol with antipyrine. J Clin Pathol 7:322-30.

15. Ellaman GL. (1959): Tissue sulfhydryl group. Arch Biochem Biophys 82:70-2.

16. Kakkar P, Dass B, Visvanathan PN. (1972): A modified spectrophotometric assay of superoxide dismutase. Indian $\mathbf{J}$
Biochem 197:588-90. Back to cited text no. 18.

17. Sinha KA. (1972): Colorimetric assay of catalase. Anal Biochem;47:389-94.

18. Lowry OH, Rosenberg NJ, Farr AL, Randall RJ. (1951): Protein measurement with Folin Phenol reagent. J Biol Chem 193:265-75.

19. Armitate P, Bregg G. (1985): In: Statistical methods in medical research. 2nd ed. London: Blackwell Scientific Publications.

20. Johnson DE, Kroening C. (1998): Mechanism of early carbontetrchloride toxicity in cultured rat hepatocytes. Pharmacol Toxicol 83:231-9.

21. Srivastava SP, Chen NO, Holtzman JL. (1990): The in vitro NADPH dependent inhibition by $\mathrm{CCl} 4$ of the ATP dependent calcium uptake of hepatic microsomes from male rats. Studies on the mechanism of inactivation of the hepatic microsomal calcium pump by the $\mathrm{CCl} 3$ radical. $\mathrm{J}$ Biol Chem 265:8392-99.

22. Maheswory, H (2005): Antihepatic effect of Grape seed oil in rats. Indian Journal of Pharmacology .37( 3):179-182. 


\section{تاثير زيت بذره العنب على كب الجرذان البيضاء}

$$
\text { افنان مصطفى عامر }
$$

كليه البنات للاداب والعلوم والتربيه- جامعه عين شمس

تم دراسه تاثير زيت بذره العنب على رباعى كلوريد الكربون المسبب لتدمير خلايا الكبد فى الجرذان

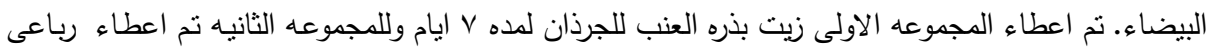

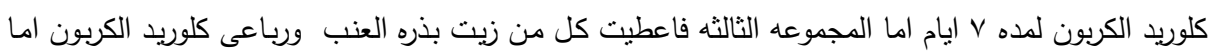

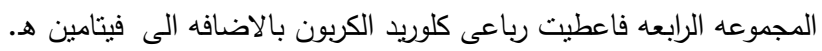

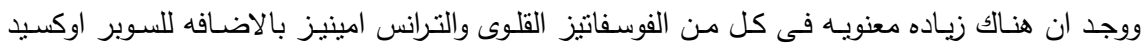

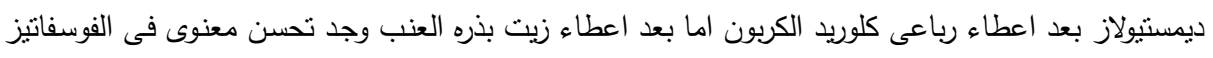
القلوى والترانس امينيز و السوبراوكسيد ديمستيولاز .

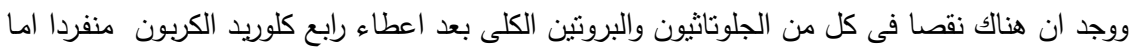

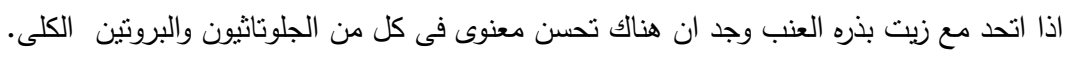

